\title{
A satisfaction survey of high-rise residential management in Malaysia: sustainable indicators
}

\author{
A. I. Che-Ani, M. Jamil, M. F. M. Zain, M. F. I. Mohd-Nor \\ $\&$ N. Mohd-Tawil \\ Department of Architecture, \\ Faculty of Engineering and Built Environment, \\ Universiti Kebangsaan Malaysia, 43600 UKM Bangi, Selangor, \\ Malaysia
}

\begin{abstract}
Living in a residential high-rise is now becoming a lifestyle trend among the urban professional community in Malaysia. As opposed to a landed property, in a residential high-rise, residents must set up a Management Corporation (MC) to regulate and manage all the amenities provided by the developer, as stipulated in the Strata Title Act of 1985. To a certain extent, the idea seems to work successfully for a few years after the housing schemes are granted with the final title. However, as time goes by and management becomes more ineffective, a gap grows between the residents and the council members of the MC, which is made up of a select group of residents. This research focuses on the indicators for sustainable facility management. We used residents' satisfaction levels as the primary measurement criteria used to identify and measure the gap between the residents and the Management Corporation, and we analysed our data using ANOVA and MANOVA. Further analysis is conducted using the Bonferonni test to determine differences among groups of respondents. The findings of this research revealed that there were significant differences in terms of satisfaction between the Management Corporation and the residents, as the Management Corporation reported a higher level of satisfaction compared to the residents in every criterion.
\end{abstract}

Keywords: facility, residential high-rise, satisfaction, sustainable indicators. 


\section{Introduction}

Living in a residential high-rise has become a trend in Malaysia today, especially among city dwellers. One of the reasons many prefer to live in a residential highrise is the facilities provided within the housing area. The residents pay a fee for the facilities provided, while the Management Corporation (MC) is responsible for managing the facilities.

The life cycle of management in a given Malaysian residential high-rise can be categorised into three periods, namely, before the establishment of the MC, during the initial establishment of the MC, and after the complete establishment of the $\mathrm{MC}$, after which the developer hands over management responsibilities completely to the residents $[1,2]$. Today, the residential high-rise is governed by the Strata Title Act of 1985 (hereafter referred to as the STA, unless otherwise specified). Malaysia's STA was adopted from the New South Wales Conveyancing Act of 1961 [3].

This paper focuses on residential high-rises managed by residents through an MC. The first two periods are not included in this study because during these periods, the management is temporary in nature and the residents have no say in managing their own property. Theoretically, in managing a residential high-rise, both parties, i.e., the MC and the residents, have to achieve a consensus on all management-related matters. This is to ensure effective management, thus contributing towards sustainable development. Unfortunately, this study found that there was a pattern of management gaps between the $\mathrm{MC}$ and residents. This paper starts by briefly discussing several key issues that may lead to a management gap. It then follows with a discussion of the methodology used in this study as well as its prominent findings.

\section{Issues in residential high-rise management}

Residential high-rises are unique properties that differ from landed properties such as bungalows or terrace houses. They are unique insofar as, after the properties have been occupied, facilities must be jointly managed by residents [4]. To address these unique issues pertaining to management and maintenance activities as well as to supplement the National Land Code that proved ineffective for residential high-rises, the STA was implemented in 1985 [5]. According to the STA, the MC is accountable for all management and maintenance aspects of the overseen properties and common facilities therein [6, 7]. Unfortunately, in our study, most of the housing schemes were not effectively managed. Residents complained about incompetent facility management, such as dysfunctional lifts, rubbish not collected according to schedule, vandalism, misuse of sinking funds, as well as disputes among residents. In short, the issues raised by residents were centred on three aspects necessary to effectively manage a facility, namely, finances, maintenance, and people, that is, the residents themselves. These three aspects are, in fact, the indicators in determining the performance of residential high-rise management. The sustainable development in this context means the achievement of housing schemes in providing equal balance of satisfaction among the aspect of finances, maintenance and people. 
Alternatively, the most challenging issue faced by management in managing a residential high-rise was collecting the monthly maintenance dues necessary to run facility management activities [2, 5, 7-9]. The maintenance dues, or charge, are a fee imposed on all the residents that is used to maintain the facilities [10]. For residential high-rises, the amount charged is based on the unit size [10]. Unfortunately, there are some residents who contend that the amount charged is higher than what they had expected, and they therefore refuse to pay.

Some residents offered rather, unpersuasive excuses to avoid paying dues; for example, some claimed that they did not fully use the facilities provided [7] or that the charge was not reasonable considering to the quality of service $[9,5]$. According to Teo [6], although the MC can legally prosecute residents in order to collect owed dues according to Sect. 52(2), Sect 53A, Sect 53(2) and Sect 55A of the STA, MCs rarely choose to do so because doing so is impractical [5]. In addition, such legal actions may affect the other residents' image [2]. When most residents neglect to pay the charge, the fund is insufficient to properly manage the facilities. As a result, most of the facility management activities cannot be carried out on time and thus affect the effectiveness of facility management for the building as a whole $[9,5]$.

These issues lead to a management gap between MCs and residents with regard to managing the facilities of residential high-rises. The management gap occurs when the services expected by the residents cannot be delivered by the $\mathrm{MC}$, thus adversely affecting the sustainable indicators. Since the residents pay on a monthly basis, they expect the facility management to be effective. Under the STA, the MC is legally required to provide the services of a management agent and as such is the party responsible for running the facility management activities. In practice, most MCs function poorly because they don't have the expertise to run and properly maintain the housing complex. If the MC fails to function as stipulated in the STA, the residents of that particular housing complex have the right to summon the said MC. Therefore, in order to avoid legal action, the $\mathrm{MC}$ normally engages a management agent in order to transfer its liability regarding the housing complex.

Even so, a management gap continues to exist, as evidenced by on-going reports in mass media on the topic [5]. Residents continue to complain about the low service quality of facility management provided by their management agents as well as the lack of responsibility of the $\mathrm{MC}$ in ensuring effective facility management. In discussing this matter, this paper uses the Malaysian case study as to analyse the sustainable indicators of residential high-rise management.

\section{The framework of sustainable indicators}

As depicted in Fig. 1, the framework shows the relationships among 12 variables in measuring the management gap. Each variable is a sustainable indicator for residential high-rises. They are categorised under three constructs, namely, finances, maintenance and resident; each of these constructs has its own dimensions. In between these constructs and dimensions, there are the different categories of respondents: member of $\mathrm{MC}$, management agent and resident. 


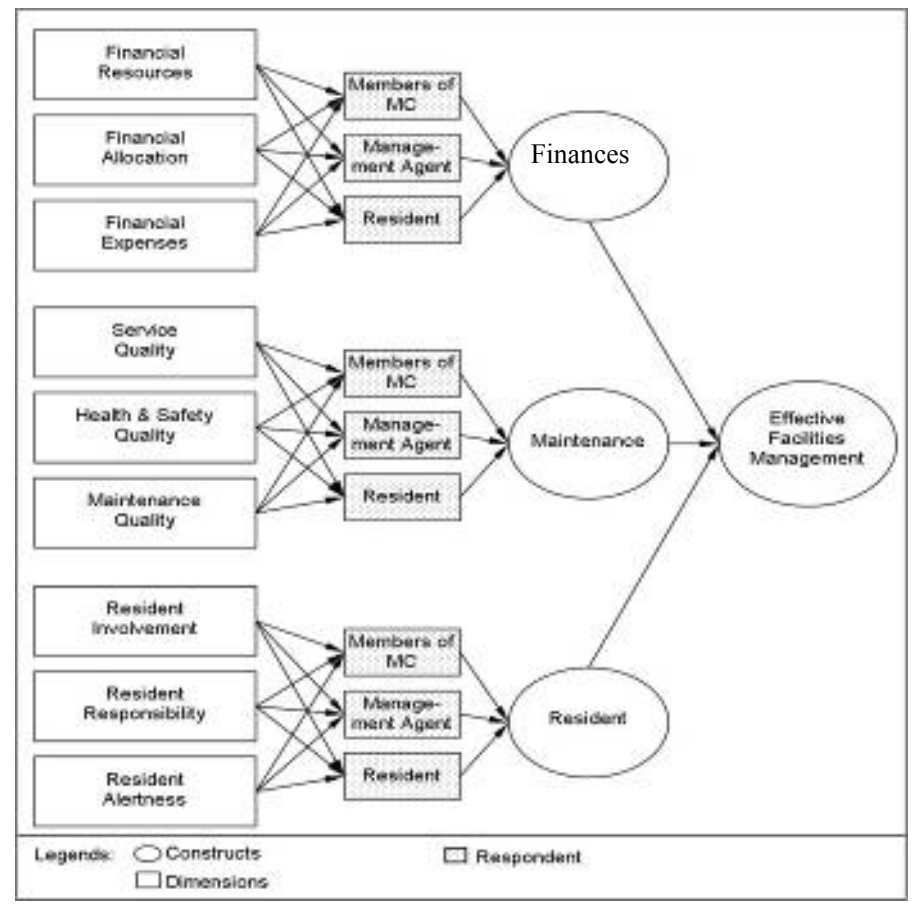

Figure 1: The research framework.

The finances construct has three dimensions, namely, financial resources, financial allocation and financial expenses. In running day-to-day activities, the MC needs resources; otherwise, little can be done. In medium- and high-cost residential high-rises, the amount of collected maintenance charges was just enough to run the facilities, even if all residents did not pay. In addition, finances should be planned via sensible allocation and monitoring of expenses. For example, allocations for cosmetic recovery should be the last agenda in housing maintenance activity [11]. Effective facility management is not merely based on the collection of funds itself but also on the capacity to effectively manage limited resources according to need [12].

The second construct, i.e., maintenance, also has three dimensions, namely, service quality, health and safety quality, and maintenance quality. Building maintenance is one of the crucial tasks in facility management [13]. It also plays a major role in providing sustainable housing. Theoretically, maintenance can be seen from a 'hard' or 'soft' perspective. The 'hard' perspective refers to the maintenance output or product insofar as the resident can see and feel the impact of maintenance work. For example, landscaping provides well-kept scenery that the resident can directly view and enjoy. The 'soft' perspective considers the service quality with regard to carrying out the particular work. This perspective focuses more on the human response, that is, customer service. With regard to safety and health quality, maintenance is often undertaken to safeguard residents' 
health; in other words, they should feel secure and comfortable living within their compounds.

Third, we consider the resident construct, which also has three dimensions, namely, resident involvement, resident responsibility and resident alertness. For facility management to be effective, the end-user must be able to respond effectively to management. The participation of residents is crucial, since all facility management activities are designed for and dedicated to them. In addition, residents pay the maintenance charges. Residents should be involved at the Annual General Meeting used to set up the MC, since this is when the amount of the monthly fee is determined and agreements are made according to the STA. Other than involvement, the residents should also understand their responsibilities as members of their residential communities. That is, they should embrace a neighbourly spirit and avoid selfishness; the extent to which residents do so appears largely dependent on the residents' background and status (owner or tenant). Finally, residents should also be alert regarding on-going changes, such as housing rules, community activities within their housing scheme, environmental conditions, and maintenance service standards, especially routine maintenance work.

\section{Methodology}

The research strategy we adopted was quantitative in nature. Our data collection technique involved a personally assisted questionnaire. The questionnaire was formulated based on the facility management variables described above, which consisted of financial, maintenance and resident constructs. These constructs are the sustainable indicators for residential high-rise management. The respondents had to respond to items based on a five-point Likert scale; these items asked about the respondent's satisfaction level. The range of the scale was $1=$ not satisfied; $2=$ less satisfied; $3=$ neutral (neither satisfied nor dissatisfied); $4=$ quite satisfied; and 5 = very satisfied. The data analysis was run using the Statistical Package for Social Sciences (SPSS), version 12.

Based on the statistics provided by the State Land Office, there were only 495 non-low-cost housing complexes that fulfilled the samples' main criterion, which was that these non-low-cost residential high-rises had already conducted their First Annual General Meeting. We sampled approximately $30 \%$ or 150 of these 495 housing schemes and thus were able to calculate our variables at a $96 \%$ confidence level (see www.custominsight.com for sampling calculations). The sample selection was conducted using SPSS. Each non-low-cost housing complex was represented by five respondents, namely, three members of the $\mathrm{MC}$, one Management Agent and one resident who had experience as a member of the MC. Therefore, we interviewed a total of 750 respondents.

In order to identify the management gap, this study analysed differences in satisfaction level using MANOVA and ANOVA. Before proceeding with MANOVA, a statistical pre-test was conducted using Levene and Box's M tests to determine the equality of variance assumptions and the variance-covariance matrix. The $\mathrm{p}$ value of both pre-tests should indicate insignificance, i.e. $p$ value $>$ 
0.05, in order to conduct MANOVA and/or ANOVA. To further analyse differences among respondent categories, this study proceeded with the Bonferonni test. We assumed that the management gap existed when there was a significant difference in levels of satisfaction among respondents.

\section{Discussion of findings}

A pilot study was first carried out involving 150 respondents in 30 housing complexes. This sample was selected randomly from the total respondents to justify the reliability of the measurement scale of each variable. According to the results from this pilot study, all the variables had internal consistency. In addition, each variable had a Cronbach's Alpha above 0.8, suggesting that each had high reliability. To determine whether a parametric or non-parametric test should be used, a normality test using the Kolmogorov-Smirnov technique was carried out. We used this technique, because our sample size was greater than 100 . In short, the $\mathrm{p}$ value was less than 0.05 , but the skewness value was between -1 and 1. Therefore, the data could be categorised as normal, and thus, the parametric test was used for statistical analysis.

The unit of analysis was the satisfaction level among the three categories of respondents, namely, the members of the $\mathrm{MC}$, the management agent and the resident. According to our research framework as per Fig. 1, this study concentrated on the analysis of satisfaction level with regards to the central concept (effective facilities management) among the three aforementioned constructs. Our analysis showed a pattern of management gap insofar as it relates to effective facility management, which also implicates the sustainable indicators. The results of this study are presented below.

Table 1: $\quad$ Levene test for constructs.

\begin{tabular}{|l|c|c|}
\hline Constructs & F statistic & P value \\
\hline Financial & 0.224 & 0.799 \\
\hline Maintenance & 0.039 & 0.961 \\
\hline Residents & 1.095 & 0.335 \\
\hline
\end{tabular}

Table 2: $\quad$ Box's $M$ test for constructs.

\begin{tabular}{|c|c|c|}
\hline Value & F statistic & P value \\
\hline 4.574 & 0.378 & 0.972 \\
\hline
\end{tabular}

Tables 1 and 2 show that there were no significant differences between the Levene and Box M tests. Therefore, MANOVA and ANOVA are valid tools to analyse to the relationship between the constructs and the respondent categories.

Based on the results in Table 3, MANOVA revealed that collectively, there was a significant difference among the constructs according to respondent category. The ANOVA also showed a significant difference in the satisfaction 
Table 3: $\quad$ Result of MANOVA and ANOVA for constructs.

\begin{tabular}{|c|c|c|c|c|c|c|}
\hline \multicolumn{5}{|c|}{ Multivariate Test } & \multirow{2}{*}{$\begin{array}{c}\text { F statistic } \\
7.717 \\
(0.941)\end{array}$} & \multirow{2}{*}{$\begin{array}{c}\begin{array}{c}\mathbf{P} \\
\text { value }\end{array} \\
0.000 *\end{array}$} \\
\hline \multicolumn{5}{|c|}{ Wilks' Lambda } & & \\
\hline Constructs & Respondent & $\mathbf{N}$ & $\begin{array}{l}\text { Mean } \\
\text { Score }\end{array}$ & $\begin{array}{l}\text { Standard } \\
\text { deviation }\end{array}$ & F statistic & $\begin{array}{c}\mathbf{P} \\
\text { value }\end{array}$ \\
\hline \multirow[t]{3}{*}{ Financial } & $\mathrm{MC}$ & 450 & 3.2737 & 1.0355 & \multirow{3}{*}{3.377} & \multirow{3}{*}{$0.035^{*}$} \\
\hline & Mgt. Agent & 150 & 3.1408 & 1.0060 & & \\
\hline & Resident & 150 & 3.0353 & 0.9916 & & \\
\hline \multirow[t]{3}{*}{ Maintenance } & $\mathrm{MC}$ & 450 & 3.2747 & 0.7139 & \multirow{3}{*}{9.163} & \multirow{3}{*}{$0.000 *$} \\
\hline & Mgt. Agent & 150 & 3.4227 & 0.6993 & & \\
\hline & Resident & 150 & 3.0754 & 0.6939 & & \\
\hline \multirow[t]{3}{*}{ Residents } & $\mathrm{MC}$ & 450 & 3.1082 & 0.7809 & \multirow{3}{*}{3.750} & \multirow{3}{*}{$0.024 *$} \\
\hline & Mgt. Agent & 150 & 3.0727 & 0.7325 & & \\
\hline & Resident & 150 & 2.9107 & 0.7579 & & \\
\hline
\end{tabular}

*Significant at 0.05 .

level of different categories of respondents for every single construct. Looking at the mean score, residents reported the lowest satisfaction level for all constructs as compared to $\mathrm{MC}$ members and management agents.

Table 4 shows further differences according to respondent category. It also depicts a pattern of significant difference, especially between MC members and residents, for each construct. In addition, there was a significant difference between management agents and residents regarding maintenance, as residents were less satisfied with maintenance as compared with management agents. Overall, it seems that residents were less satisfied than the other respondents for all three constructs. In other words, our analysis showed a management gap in terms of facility management in residential high-rises. To make our results more generalisable, we discuss the concept of effective facility management below.

The pre-test shown in Table 5 (where the $\mathrm{p}$ value indicates insignificance demonstrates that it is appropriate to conduct an ANOVA to analyse the relationship between respondent category and satisfaction level regarding the effectiveness of facility management. Based on Table 6, there is a significant difference in satisfaction level among respondents regarding effectiveness. Moreover, the satisfaction level of residents was lower than that of other respondents.

Table 7 shows that the only significant difference in satisfaction level regarding effectiveness of facility management was between MC members and residents; residents were generally less satisfied. This finding further confirms the existence of a management gap with regards to facility management of residential high-rises. 
Table 4: $\quad$ Results of the Bonferonni test for constructs.

\begin{tabular}{|l|l|l|c|c|}
\hline Constructs & Respondent & Respondent & $\begin{array}{c}\text { Difference of } \\
\text { mean score }\end{array}$ & P value \\
\hline \multirow{4}{*}{ Financial } & $\mathrm{MC}$ & Mgt. Agent & 0.1329 & 0.503 \\
\cline { 2 - 5 } & $\mathrm{MC}$ & Resident & 0.2384 & $0.040^{*}$ \\
\cline { 2 - 5 } & Mgt. Agent & Resident & 0.1055 & 1.000 \\
\hline \multirow{3}{*}{ Maintenance } & $\mathrm{MC}$ & Mgt. Agent & -0.1480 & 0.080 \\
\cline { 2 - 5 } & $\mathrm{MC}$ & Resident & 0.1992 & $0.009^{*}$ \\
\cline { 2 - 5 } & Mgt. Agent & Resident & 0.3472 & $0.000^{*}$ \\
\hline \multirow{3}{*}{ Residents } & MC & Mgt. Agent & 0.0355 & 1.000 \\
\cline { 2 - 5 } & MC & Resident & 0.1975 & $0.019^{*}$ \\
\cline { 2 - 5 } & Mgt. Agent & Resident & 0.1620 & 0.203 \\
\hline
\end{tabular}

* Difference of mean score was significant at 0.05 .

Table 5: $\quad$ Levene test for effectiveness.

\begin{tabular}{|l|c|c|}
\hline Concept & F statistic & P value \\
\hline Effectiveness & 0.916 & 0.400 \\
\hline
\end{tabular}

Table 6: $\quad$ Results of the ANOVA for effectiveness.

\begin{tabular}{|l|l|c|c|c|c|c|}
\hline Concept & Respondent & $\mathbf{N}$ & $\begin{array}{c}\text { Mean } \\
\text { Score }\end{array}$ & $\begin{array}{c}\text { Standard } \\
\text { deviation }\end{array}$ & $\begin{array}{c}\text { F } \\
\text { statistic }\end{array}$ & P value \\
\hline Effectiveness & MC & 450 & 3.4015 & 1.0774 & & \\
\cline { 2 - 5 } & Mgt. Agent & 150 & 3.2222 & 1.0105 & \multirow{2}{*}{3.851} & $0.022^{*}$ \\
\cline { 2 - 5 } & Resident & 150 & 3.1489 & 1.0981 & & \\
\hline
\end{tabular}

*Significant at 0.05 .

Table 7: $\quad$ Results of the Bonferonni test for effectiveness.

\begin{tabular}{|l|l|l|c|c|}
\hline Concept & Respondent & Respondent & $\begin{array}{c}\text { Difference of } \\
\text { mean score }\end{array}$ & P value \\
\hline \multirow{2}{*}{ Effectiveness } & MC & Mgt. Agent & 0.1792 & 0.227 \\
\cline { 2 - 5 } & MC & Resident & 0.2525 & $0.037^{*}$ \\
\cline { 2 - 5 } & Mgt. Agent & Resident & 0.0733 & 1.000 \\
\hline
\end{tabular}

*Difference of mean score was significant at 0.05.

Based on the analysis above, the main reason for all the issues that have arisen in the facility management of residential high-rises in Malaysia is now clear. The management gap not only exists but also forms a barrier to providing effective facility management. Note that the residents were always found to be less satisfied than MC members. The management gap can be termed as 'inhouse' shortfalls, since in almost all cases, there was no significant difference between the satisfaction levels of the management agents, with the MC members 
and the residents. Based on these findings, the management gap appeared to still be in its infancy among sampled housing complexes; in short, it was not considered to be serious, since the difference in mean score was not more than 1 . Therefore, there is still room for improvement for both parties. The MC and residents may be able to rectify their relationship and minimise the management gap through more effective facility management. In regards to sustainable indicators, our analysis shows that the management of residential high-rises is not sustainably managed as a whole.

\section{Conclusion}

This paper has discussed the management gap as an indication of sustainable management in residential high-rises in Malaysia. The management gap exists when there is significant difference in satisfaction levels among respondents regarding various components of facility management, including finances, maintenance, and resident aspects, as well as regarding the effectiveness of management. The issue of facility management in residential high-rises is reported quite extensively in the mass media, which suggests the existence of such a gap. This study has confirmed the management gap, which indicates that housing management in Malaysia on the whole has yet to embrace a sustainable management agenda. This gap also has been a barrier for both the Management Corporation and residents as they cooperate in effective facility management.

The identification of the management gap also contributes to the so-called 'chicken and egg' debate within the literature on MCs. According to our data, the management gap is not yet at a serious stage, thus yielding an opportunity for the parties involved to minimise the gap. Since this condition could worsen in the near future, it is necessary to identify the exact needs and expectations of both parties vis-à-vis each other. Since there was no significant difference with the residents and $\mathrm{MC}$ members in the perspective of management agents (except regarding maintenance), we suggest that the management agents act as mediators in bridging the management gap. With this suggestion, we hope to brighten the possibilities of achieving sustainable housing management in the future.

\section{References}

[1] DBKL, Hak Milik Strata \& Perbadanan Pengurusan (Strata Title \& Management Corporation), JPPH; JPP, Kuala Lumpur City Council (DBKL), 1999.

[2] Sapian, I., Pengurusan Penyenggaraan Bangunan \& Kualiti Kehidupan Di Kondominium Di Malaysia (Building Maintenance Management \& Condominium Living Quality In Malaysia), $2^{\text {nd }}$ Building Management \& Maintenance Seminar, 22-23 December 2003, Kuala Lumpur, 2003.

[3] Alinah, A., Taklimat Penubuhan PraPerbadanan Pengurusan (Briefing on the Establishment of Pre-Management Corporation), Housing Development Board, Selangor, Malaysia, 2004. 
[4] Linariza, H.; Ashok, V., Facility Management: An Introduction. The Malaysian Surveyor, 1st Quarter 2003 (38.1), pp. 13-19, 2003.

[5] Tiun, L. T., Managing High-Rise Residential Building In Malaysia: Where Are We? Social Science Association, University Putra Malaysia, 8-10 August 2006, Faculty of Ecology, University Putra Malaysia, 2006.

[6] Teo, K. S. (translation), Hak Milik Strata Di Malaysia (Strata Title in Malaysia), Kuala Lumpur: Dewan Bahasa \& Pustaka, 1993.

[7] Jamila, H., Strata Title in Malaysia. Selangor: Pelanduk Publications (M) Pte. Ltd., 1994.

[8] Liias, R., Housing Stock: The Facilities for Future Development. Journal of Facilities, (16) 11, pp. 288-294, MCB University Press, 1998.

[9] Malaysia Government, Housing in the New Millennium - Malaysian Perspective, Address: http://www.kpkt.gov.my/jabatan/jpn/artikel3.htm [Accessed: 7 Sept 2004], Update: July 2003, 1999.

[10] Malaysia Government, Panduan Kehidupan Bersama Dalam Bangunan Bertingkat (Guideline of Community Living In Multi-storey Residential), Edition 1, Jabatan Ketua Pengarah Tanah \& Galian, Kementerian Sumber Asli \& Alam Sekitar, 2003.

[11] Amarilla, B.; Dunowicz, R.; Hasse, R., Social Housing Maintenance. Proc. of the XXX IAHS World Congress on Housing. 9-13 September 2002, eds. Ural, O., Abrantes, V., Tadeu, A., Portugal: Pedro Batista - Artes Graficas, Lda. pp. 1951-1957, 2002.

[12] Hui, E. Y. Y., Key Success Factors of Building Management in Large \& Dense Residential Estates. Journal of Facilities, (23) 1/2, pp. 47-62, MCB University Press, 2005.

[13] Thompson, P., The Maintenance Factor in Facilities Management. Journal of Facilities, (12) 6, pp. 13-16, MCB University Press, 1994. 